Abstracta Iranica

Revue bibliographique pour le domaine irano-aryen

Volume 32-33 | 2013

Comptes rendus des publications de 2009-2010

\title{
Irène Natchkebia. La place de la Géorgie dans le traité de Finkenstein (1807)
}

\section{Giorgio Rota}

\section{(2) OpenEdition \\ 1 Journals}

\section{Electronic version}

URL: http://journals.openedition.org/abstractairanica/40675

DOI: 10.4000/abstractairanica.40675

ISSN: 1961-960X

Publisher:

CNRS (UMR 7528 Mondes iraniens et indiens), Éditions de l'IFRI

\section{Printed version}

Date of publication: 1 December 2013

ISSN: 0240-8910

\section{Electronic reference}

Giorgio Rota, «Irène Natchkebia. La place de la Géorgie dans le traité de Finkenstein (1807) 》, Abstracta Iranica [Online], Volume 32-33 | 2013, document 251, Online since 01 July 2016, connection on 27 September 2020. URL : http://journals.openedition.org/abstractairanica/40675 ; DOI : https://doi.org/ 10.4000/abstractairanica.40675

This text was automatically generated on 27 September 2020 .

Tous droits réservés 


\title{
Irène Natchkebia. La place de la Géorgie dans le traité de Finkenstein (1807)
}

\author{
Giorgio Rota
}

\section{REFERENCES}

Irène Natchkebia. «La place de la Géorgie dans le traité de Finkenstein (1807) 》, in :

Florence Hellot-Bellier et Irène Natchkebia, éds., La Géorgie entre Perse et Europe. Paris, L'Harmattan, 2009, p. 115-141.

1 In the spring of 1807, Napoleon announced that he wanted to create a triple alliance between France, Persia and the Ottoman Empire, all of which were warring against Russia. The alliance with Persia stemmed from Napoleon's old dream of attacking British India overland through the Middle East. In March of the same year, a Persian ambassador met the Emperor of the French in Warsaw. Natchkebia recounts in great detail the negotiations that led to the signing of the Treaty of Finkenstein on 4 May 1807 between Napoleon and Fatḥ-'Alī Šāh Qājār, as well as the subsequent events. Napoleon acknowledged the latter's rights over Georgia and obliged himself to force Russia to withdraw from the region as well as from the other territories occupied during the war that had started in 1804. A comparison of the treaty's final text with the first draft shows that the latter was amended in order to provide for a more active French role in the conflict. As early as 4 April (a month before the treaty was signed), Napoleon appointed Brigadier General Gardane as ambassador to Persia. On 7 July 1807 however, little more than two months after the signature, Napoleon made peace with the Russian Tsar at Tilsit. This decision doomed Gardane's mission, even though the ambassador remained in Tehran from 4 December 1807 till 13 February 1809. He had to face the understandable disappointment of the Shah and his government: without the possibility of recovering Georgia, the alliance with France lost its appeal to Persia. Napoleon's grandiose plan did not achieve any political or military results other than 
pushing Persia into Britain's arms. There were results in the domain of culture however.

2 The members of the Gardane mission, like their predecessors at the Qajar court, collected a wealth of information. The author has done research on this and written a number of valuable scholarly texts. On the eve of the Treaty of Finkenstein, the French press ran three articles about Georgia, its history and culture: the bravery of the Georgians was praised, and the land and the rest of the Caucasus were described as a goldmine for scholars. While this was probably an attempt by Napoleon to manipulate public opinion, these articles (translated from Russian via German) might have marked the beginning of Georgian studies in France.

\section{AUTHORS}

GIORGIO ROTA

Institut für Iranistik, Wien 